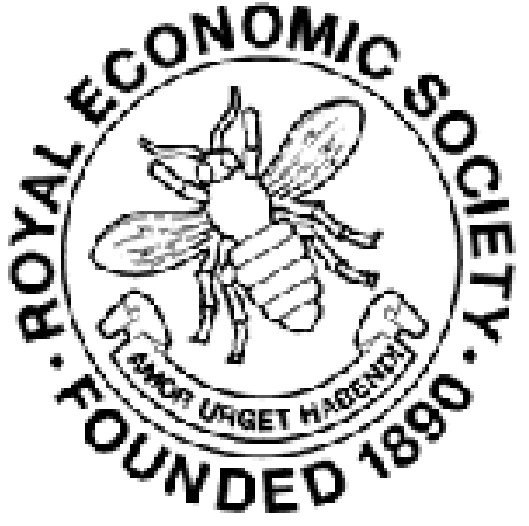

\title{
Railway Economics
}

Author(s): W. M. Acworth

Source: The Economic Journal, Vol. 2, No. 6 (Jun., 1892), pp. 392-398

Published by: Wiley on behalf of the Royal Economic Society

Stable URL: http://www.jstor.org/stable/2956177

Accessed: 26-06-2016 05:11 UTC

Your use of the JSTOR archive indicates your acceptance of the Terms \& Conditions of Use, available at

http://about.jstor.org/terms

JSTOR is a not-for-profit service that helps scholars, researchers, and students discover, use, and build upon a wide range of content in a trusted digital archive. We use information technology and tools to increase productivity and facilitate new forms of scholarship. For more information about JSTOR, please contact support@jstor.org.

Royal Economic Society, Wiley are collaborating with JSTOR to digitize, preserve and extend access to The Economic Journal 
suggested any government intervention, except to some extent for the restriction of overtime, especially in government contracts. They are not in favour of an eight-hours day except in Scotland.

JoHN RAE

\section{RaILWAy Economics.}

Whат is the explanation of the entire neglect by English economists of the subject of railway economics? How absolute that neglect is may be judged by one or two instances. In the last edition of the Encyclopadia Britannica, the portion of the article on railways which deals with other than technical questions of construction and exploitation is by Professor Hadley, an American. In Professor Hadley's own admirable work on Railroad Transportation, there is at the head of the chapter dealing with each country a short list of the principal authorities. For the economic history of English railways Mr. Hadley refers his English-speaking readers to the Untersuchungen iiber die Englische Eisenbahnpolitik of Gustav Cohn, an Austrian professor. In his recent popular account of the Working and Management of an English Railway, Mr. Findlay does indeed acknowledge his indebtedness to two English books. But the one was published in 1856, the other in 1851.

It is no accident that the authorities referred to by Mr. Findlay are forty years old. For in the early days of railways there were a considerable number of serious English books on this subject, and, to say nothing of Fairbairn's Political Economy of Railroads, published as early as 1836, works such as The Influence of English Railway Legislation on Trade and Industry, published in 1848, by James Morrison, sometime M.P. for Inverness, or Dr. Lardner's Railway Economy, published in 1850, were fully abreast of the knowledge of the day, and doubtless more than on a level with any railway literature then available in foreign countries. But since then, while the foreigners have published a great deal, English economists have turned their backs on the whole subject: I know but two English books of recent date which even pretend to discuss the economic basis of railway tariffs and railway legislation. The one is Railway Rates English and Foreign, published in 1886, by Mr. James Grierson, the late general manager of the Great Western Railway; the other The Railways and the Traders, published last year, by the present writer. But neither of these books can possibly be regarded as an authority on the subject of which they treat, for their authors could make no claim to the title of political economists ; their books were in both cases written to serve a temporary purpose, and consequently are full of merely ephemeral matter; and lastly, they are professedly the utterances of advocates, though of advocates firmly convinced of the justice of the cause they champion, instead of being the judicial opinion of unbiassed observers. ${ }^{1}$ For a

1 There is of course not a little valuable matter scattered through the reports and evidence of the Parliamentary Committees and Royal Commission which sat in 
scientific treatise on the economic laws governing the relations between railways and the public and the legislature, which could be placed in the hands of a student as a text-book, the fellow countrymen of Adam Smith and George Stephenson must betake themselves either to the Continent or to the other side of the Atlantic.

For it is fortunate that this strange neglect of railway problems is confined to Great Britain. The United States alone has produced quite a considerable crop of railway literature within the last few years. First and foremost comes Professor Hadley's brilliant book on Railroad Transportation, its History and its Laws, which doubtless owes its title, as also in some degree its inspiration, to the equally brilliant series of monographs collected by Albert Fink under the name of Railroad Transportation. Here is a further list, which of course makes no profession to be in any way exhaustive :-

C. F. Adams, Railroads, their Origin and Problems.

Alexander, Railway Practice.

Hudson, The Railways and the Republic.

Dabney, The Public Regulation of Railways.

Stickney, The Railway Problem.

Kirkman, Railway Rates and Government Control.

To these one might add the following monographs:-

Alexander, Reply to Questions of the New York Chamber of Commerce.

Vining, The Necessity for a Classification of Freight and the Principles on which it is based

Fink, Report on the Adjustment of Transportation Rates to the Seaboard. Described by Professor Hadley as 'one of the most successful applications ever made of mathematical methods to social phenomena.'

Professor Taussig, Contribution to the Theory of Railway Rates.

Professor James, 'Reform in Railway Passenger Fares' (Quarterly Journal of Economics).

Seligman, 'Railway Tariffs and the Inter-State Commerce Law' (Political Science Quarterly).

In the reports of the various State Railway Commissions, and more especially in those of the Inter-State Commerce Commission (whose chairman was till a few months back Judge Cobley, one of the professors of the Michigan University and the greatest living authority on American Constitutional Law, and at the head of whose statistical department is Professor H. C. Adams, likewise of the Michigan University), will also be found not a little matter of economic interest.

If we turn from America to the Continent of Europe, we shall find that there, too, quite a large number of books on railway subjects have been published in recent years, some of them at least by economists of

$1853,1867,1872,1881,1882$. But one needs to commence with a firm grasp of the leading principles of the correct railway creed in order to be able to separate the peck of wheat from the bushels of chaff with which it is mixed. 
established position. Gustav Cohn's Untersuchungen über die Englische Eisenbahnpolitik has already been mentioned. Here are a few other German (including Austrian) authorities. ${ }^{1}$

Dorn, Aufgaben der Eisenbahnpolitik.

Sax, Die Verkehrsmittel in Volks- und Staatswirthschaft.

Von Weber, Nationalität und Eisenbahnpolitik.

Der Staatliche Einfluss auf die Entwickelung der Eisenbahnen minderer Ordnung.

Professor Launhardt, Theorie der Tarifbildung der Eisenbahnen.

Dr. v. d. Leyen, Die Nordamerikanischen Eisenbahnen.

Die Durchführung des Staatsbahnsystems in Preussen (Jahrbuch für Gesetzgebung, 1883).

Haberer, Geschichte des Eisenbahnwesens.

Schreiber, Tarifwesen der Eisenbahnen.

Professor Adolph Wagner, Communications- und Transportwesen.

Dr. Julius Lehr, Eisenbahntarifivesen und Eisenbahnmonopol.

Ulrich, Eisenbahntarifwesen im Allgemeinen.

Personentarifreform und Zonentarif.

Dr. Otto Michaelis, Differenzialtarife der Eisenbahnen.

No English economist, as far as I am aware, has condescended to notice the sweeping reductions of passenger fares and more recently of goods rates in Hungary, in Austria, and in neighbouring countries, which have been effected by the introduction of what is, unfortunately perhaps, known to us as the 'zone system.' Yet surely if English fares and rates could be reduced by one-half-and this is something like what has been done in Hungary -if $\$ 40,000,000$ sterling, now annually paid to the railway companies, could be left in the pockets of the British public, it would be a revolution by the side of which the introduction of a free breakfast table or of $£ 1$ notes, or even the rearrangement of the death duties and the taxation of ground values would be but a bagatelle. I am far from saying that such a reduction is practically possible in this country; for my own part I believe it to be an impossibility ; but the contrary position is at least arguable; and it is surely remarkable that no English economist has even considered it worth discussing. Of course the subject has in its own country a considerable literature. Here are two or three titles :-

Dr. Theodor Hertzka, Das Personenporto. Ein Vorschlag zur Durchführung eines billigen Einheitstarif.

Professor Scharling, Das Personenporto der Eisenbahnen.

Dr. Eduard Engel, Eisenbahnreform.

This is not a bibliography, so suffice it to mention further, among French books Colson's admirable Transports et Tarifs, which I have ventured to recommend to English readers in the January number of the Nineteenth Century, and Picard's works, Les Chemins de Fer

1 Let me say frankly that, there being no such thing in England as a railway library, even of the most rudimentary character, most of the German books are only known to me by quotations and at second hand. 
Français and Traité des Chemins de Fer, and as of Italian origin the yet more monumental volumes containing the Atti della Commissione d'Inchiesta sull' Esercizio delle Ferrovie Italiane.

But it is not only in the matter of books that English students of railway economics are at so serious a disadvantage. There are few technical publications more ably edited and conducted than the American Railroad Gazette and Railway Review. France has the Annales des Ponts et Chaussées, dealing with a wider range of subjects than its name implies, and the Revue Générale des Chemins de Fer; Germany the Archiv für Eisenbahnwesen, the Eisenbahnvereinszeitung, and the Oesterreichische Eisenbahnzeitung; the very Argentine Republic has the River Plate Railway News. England has two or three excellent engineering papers; two journals published by the railway trade unions; three financial organs which, as the railway capital is larger than that of all the other joint-stock undertakings in the country put together, give the word 'railway' a prominent place on their title-page ; but of railway newspapers in the sense in which the name is understood elsewhere-journals, that is, in which serious questions of railway economic policy can be discussed by experts, as medical questions are discussed in the Lancet, or legal questions in the Law Times-not one.

Yet again. The curriculum of our great universities has been widened and extended of late years till a middle-aged graduate can hardly find his way about a modern university calendar; while as for the University Extension lecturers, they seem to have taken all knowledge to be their province. With one exception, however. Political economy is a frequent subject enough, but no one ever heard of a course of lectures on railway economics. And yet to the students at Derby or Doncaster, at Crewe or Gateshead, the subject should surely be at least as interesting as the theory of rent or the principles of banking. Other countries at any rate make provision for instruction on the subject. During the current 'Semester' there are courses of railway lectures in the Prussian Universities of Berlin, Breslau and Cologne. In France, in addition to the courses dealing with railway administration and railway law at the Ecole des Ponts et Chaussées and de Droit respectively, there is a special course on railway economics annually delivered by M. Colson at the École des Hautes Études Commerciales, which was founded by the Paris Chamber of Commerce. From the chair of political economy at the Yale University in Connecticut Professor Hadley has lectured on the same subject for a good many years past. Within the last few months a railway official has presented to the Stanford University a railway library of some two thousand volumes, and a sum of money in addition, sufficient to make the collection practically exhaustive of its subject. Our English railway men, on the other hand, are left either to pick up laboriously bit by bit the principles which ought to guide their practice, or else to go on all their lives acting merely by rule of thumb. As for the bulk of those who in the press or in Parliament attempt to guide the public on these 
questions, they have not so much as heard that there exist any principles of railway economics at all.

An appeal to English economists to put an end to this state of affairs should surely not be without weight if it were made merely on the ground that the application to a subject so peculiarly English as railways of a science so peculiarly English as political economy should not be left wholly in the hands of foreigners. But it is possible to base the case on the yet stronger ground of immediate practical interest. Here are taken at random half a dozen questions eminently deserving of investigation by trained economists.

I. By the Cheap Trains Bill of last year, which the House of Commons very nearly read a second time in spite of the opposition of the Board of Trade, it was proposed to compel railway companies to run workmen's trains into London at a maximum fare of one farthing per mile. Assuming some such policy to be carried out, what would be its economic effect? Would the workman keep for himself the $2 s$. or so per week which he would cease to pay to the railway company? Or would part go to his employer as a rate in aid of wages and part to the suburban landlord as additional rent? And what would be the effect on the rents and the rateable value of the working-class districts in the heart of the metropolis?

II. The Metropolitan and Metropolitan District Railways pay at present in rates, taxes, and Government duty about $\$ 80,000$ per annum, or in other words, the equivalent of the interest on two millions of capital. Their competitors, the omnibuses, pay practically speaking neither rates nor taxes, and consequently can afford to undersell them. Seeing that the railway companies provide and maintain their own roads, while the omnibuses are responsible not only for a large part of the wear and tear of existing streets but also for the enormous cost of opening new thoroughfares to accommodate the ever-increasing traffic, might it not be an economically sound policy to remit the $£ 80,000$ of taxation, if thereby the streets could be relieved of a considerable portion of the omnibus traffic?

III. Here is a much more serious matter. In every Continental country light railways and steam tramways are increasing enormously year after year in districts which cannot afford support for more expensive lines. There is a perfect network of such lines in Holland. In Italy, poor as the country is, hundreds of kilometres have been opened within the last half-dozen years ; and it is largely due to the development of steam tramways that the Italian export of agricultural produce has increased so rapidly of late. With us the mileage of steam tramways (except for passenger traffic in the suburbs of great towns) could almost be counted on the fingers of two hands. What is the reason? It cannot be that tramway construction in the Eastern Counties, for instance, is naturally expensive. If Lombardy can afford to lay down tramways along country roads and Lincolnshire cannot; if Lombard agriculture is consequently flourishing, while that of 
Lincolnshire is depressed, may not the explanation be that artificial obstacles, either of legislation, or of Board of Trade, or Highway Board regulations, obstruct a natural and desirable development?

IV. Or again. Is it in the public interest that further railway development in remote districts has been made practically impossible by Act of Parliament? For this is really the effect of the Railway Regulation Act of 1889 as interpreted by the Board of Trade. Under the orders of that Board a standard of construction and a method of working which are excellently suitable for the main line of the NorthWestern between London and Rugby is applied with cast-iron rigidity to lines in Caithness, in Cardigan, or in Cornwall, with four or six trains in the twenty-four hours. Theoretically no doubt the public safety is thereby secured. In fact, however, the cost of making and working the line being prohibitory, no railway is made; the public continues to travel in the carrier's cart; and the carrier's cart is a conveyance by whose side a train drawn by the engine of the most reckless of 'runners' over an American 'wild-cat' line were a paragon of safety.

V. More important still is the question of goods rates. The railway rates controversy has, after ten years of agitation, at length been brought to a close in Parliament. Next year we may look to see the contest transferred from Westminster to the Strand, where the Railway Commission will have to interpret the not over lucid provisions of the Act of 1888 and the new schedules of rates which have been based upon it. To a considerable extent, no doubt, the decisions under the old Acts will still be a guide; but those decisions in some cases went very near to saying that rates must be based upon cost of carriage, and this is a theory of rate-making that economists will hardly be found to support. Largely, however, the Commission will have, within the wide limits laid down by the Statute, to act upon its own discretion. And that the points submitted for its decision will often have to be decided by economic and political considerations rather than as mere points of law, must be evident to any one who reads cases such as those of the Liverpool Corn Traders' Association. If a Traders' Association in Liverpool forces the North-Western to raise the corn rates from Cardiff to Birmingham, the consequences are unimportant enough. But if a Liverpool Ship-Owners' Association were to employ the same line of argument successfully, in order to establish something like an equality in the rates per mile from Manchester to Liverpool and to London respectively, and so to send not only the Peninsular and Oriental Company but the East India Docks into liquidation, public opinion would soon awake to the practical importance of the question. What we require is not so much a treatise by a lawyer to tell us what the law of undue preference is, as one by an economist to tell us what, in the interest of the public at large, it ought to be.

VI. Lastly, there is room for another treatise on 'Indirect Protection.' The railway tariffs of most civilised countries agree in 
making the rates per mile decrease as the number of miles increase. If for instance a ton of meat from York to London costs 55s., from Stromness via York to London, which is more than four times the distance, it will cost not $220 \mathrm{~s}$. but only $90 \mathrm{~s}$. There are therefore those who assert that to charge American meat 25s. for the fraction of its journey made over English rails from Liverpool to London, while English meat, which has to pay for carriage only between these two local points, is charged $40 s$., is simply to adopt the customary method of tarification, and that those who protest that the rates should be equal on English and foreign meat are, whether they are aware of it or no, merely Protectionists seeking to discriminate against the American meat because it is foreign. Here is a matter which well deserves to be investigated by economists. For we are commonly assured that a return to Protection is impossible, that the working classes will never submit to a tax on food. Yet this is a proposed tax on food which the working man's representatives in Parliament evidently believe that he will submit to with alacrity.

But I will say no more lest I should appear to dogmatise where I am anxious only to appeal for guidance. Of questions such as these, concerning the most important of all English industries,- - the one industry without which all the others are impossible-no one surely can doubt the importance. No one, I believe, who has attempted to understand them will doubt their complexity. How much longer will English economists be content to leave the lay public to grapple with them unaided?

W. M. Acworth

\section{The Economic Condition of Russia.}

WhiLe Europe generally has economically been advancing rapidly, Russia has been falling backwards. Russia now is in the condition in which Ireland was in the first half of the century, in which India and China still are, that is to say, the bulk of its people live so close to the verge of destitution that they are plunged into famine by the failure of a single harvest. The crops of 1887 and 1888 were the best perhaps of the present century; those of 1889 and 1890 were fairly good; but the yield of 1891 was about 25 per cent. short; and the result of this deficiency of a single year is a dreadful famine in the centre and the south, that is in some of the very richest provinces of the Empire. The wretchedness of the Russian peasantry is often attributed to the 'Mir,' or village community system. No doubt, that system discourages individual enterprise, and checks improvement in husbandry; but it is to be recollected that the system has existed from time immemorial, and that it has not prevented the Russian population from rising to its present stage of civilisation, nor from building up one of the greatest empires in the world. Again, it is sometimes said that the cutting down of the forests has been carried 